\begin{tabular}{c}
\hline \hline Juntendo \\
Research Profiles \\
\hline \hline Juntendo Medical Journal \\
2016. $62(1), 54-55$
\end{tabular}

\title{
Department of Ophthalmology
}

\section{Professor and Chair: Akira MURAKAMI}

Our research projects are focused on 1) the molecular and genetic studies of inherited eye diseases, 2) immunological studies of ocular diseases, 3) the cornea and ocular surface, and 4) clinical treatments of the retina. Another important axis of our department includes work with the World Health Organization (WHO) on public health approaches for preventing blindness.

\section{Research Groups and Principle Investigators}

\section{1) Molecular genetics}

\section{Akira MURAKAMI (Professor) \\ Takuro FUJIMAKI (Associate Professor)}

Our research is focused on understanding the genetic bases and biochemical mechanisms of hereditary eye diseases, including the study of corneal dystrophies, retinal dystrophies, and optic neuropathy. One of our main goals is to establish clinical application of the results of genetic studies for diagnostic, prognostic, or pharmacological practices. Recently, we started establishing iPS cells from patients with inherited retinal degeneration diseases. This project is in collaboration with the University of Tokyo, Division of Molecular and Developmental Biology (Sumiko WATANABE). In vitro differentiation of these iPS cells into retinas, using a 3D organ culture system, was established to elucidate the molecular mechanisms of retinal degeneration and to develop new treatments.

\section{Publications:}

1) Watanabe S, Murakami A: Regulation of Retinal Development via the Epigenetic Modification of Histone H3. Adv Exp Med Biol, 2016; 854: 635-641.

2) Coppieters F, Todeschini AL, Fujimaki T, et al: Hidden genetic variation in LCA9-associated congenital blindness explained by 5'UTR mutations and copy-number variations of NMNAT1. Hum Mutat, 2015; 36: 11881196.

3) Iida A, Iwagawa T, Baba Y, et al: Roles of histone H3K27 trimethylase Ezh2 in retinal proliferation and differentiation. Dev Neurobiol, 2015; 75: 947-960.

4) Iida A, Iwagawa T, Kuribayashi H, et al: Histone demethylase Jmjd3 is required for the development of subsets of retinal bipolar cells. Proc Natl Acad Sci U S A, 2014; 111: 3751-3756.
5) Suzuki T, Fujimaki T, Yanagawa A, et al: A novel exon 17 deletion mutation of RPGRIP1 gene in two siblings with Leber congenital amaurosis. Jpn J Ophthalmol, 2014; 58: 528-535.

6) Mochizuki Y, Iida A, Lyons E, et al: Use of cell type-specific transcriptome to identify genes specifically involved in Müller glia differentiation during retinal development. Dev Neurobiol, 2014; 74: 426-437.

7) Usui A, Mochizuki Y, Iida A, et al: The early retinal progenitor-expressed gene Sox11 regulates the timing of the differentiation of retinal cells. Development, 2013; 140: $740-750$.

8) Usui A, Iwagawa T, Mochizuki Y, et al: Expression of Sox4 and Sox11 is regulated by multiple mechanisms during retinal development. FEBS Lett, 2013; 587: 358-363.

\section{2) Laboratory of ocular atopic diseases}

\section{Akira MASUDA (Associate Professor)}

\section{Nobuyuki EBIHARA (Professor)}

We focus on the pathophysiological analysis of ocular atopic diseases (atopic keratoconjunctivitis, atopic cataract, atopic glaucoma, and atopic retinal detachment). Since our pioneering report of the genetic association between ST2L (IL-33R) and atopic dermatitis in 2005 , we have been investigating the roles of the IL-33/ST2 signaling pathway in ocular allergy using human samples and mouse models. We have also performed several immunohistological studies to clarify the roles of mast cells and local IgE synthesis in the pathophysiology of allergic conjunctivitis.

As for clinical application, our research has contributed to the introduction of tacrolimus eye drops for the treatment of ocular allergic diseases. We also performed a pathophysiological study of atopic cataracts, and very recently, we proposed that 'atopic glaucoma' is a distinct clinical entity, which tends to be refractory. Atopic reactions in the eye may cause tissue fibrosis and subsequent deterioration of visual functions. We are now engaged in projects investigating the control of ocular tissue fibrosis induced by chronic ocular atopic diseases.

Publications:

1) Shimizu M, Matsuda A, Yanagisawa K, et al: Functional SNPs in the distal promoter of the ST2 gene are 
associated with atopic dermatitis. Hum Mol Genet, 2005; 14: 2919-2927.

2) Matsuda A, Okayama Y, Terai N, et al: The role of interleukin-33 in chronic allergic conjunctivitis. Invest Ophthalmol Vis Sci, 2009; 50: 4646-4652.

3) Asada Y, Nakae S, Ishida W, et al: The roles of epithelial cell-derived type 2 initiating cytokines in experimental allergic conjunctivitis. Invest Ophthalmol Vis Sci, 2015; 56: 5194-5202.

4) Iwamoto S, Asada Y, Ebihara N, et al: Interaction between conjunctival epithelial cells and mast cells induces CCL2 expression and piecemeal degranulation in mast cells. Invest Ophthalmol Vis Sci, 2013; 54: $2465-2473$.

5) Matsuda A, Ebihara N, Yokoi N, et al: Lymphoid neogenesis in the giant papillae of patients with chronic allergic conjunctivitis. J Allergy Clin Immunol, 2010; 126: $1310-1312$.

6) Fukushima A, Ohashi Y, Ebihara N, et al: Therapeutic effects of $0.1 \%$ tacrolimus eye drops for refractory allergic ocular diseases with proliferative lesion or corneal involvement. Br J Ophthalmol, 2014; 98: 10231027.

7) Hori K, Matsuda A, Ebihara N, et al: Involvement of plasminogen activator inhibitor-1 in the pathogenesis of atopic cataracts. Invest Ophthalmol Vis Sci, 2012; 53: 1846-1851.

\section{3) Public health activities and research team} Yoshimune HIRATSUKA (Senior Associate Professor)

\section{Koichi ONO (Associate Professor)}

Our department has been designated as a WHO Collaborating Centre for the prevention of blindness since 1980. Research pursued by the public health team is concerned with policy, epidemiological and economical research on various systems within the field of eye-health and welfare, as well as human resource development in collaboration with other domestic or international organizations. In particular, as a WHO Collaborating Centre, we intend to be active in research on overall systems to provide eye-healthcare services to the community from a public health perspective.

\section{Publications:}

1) Hiratsuka Y, Yamada M, Akune Y, et al: EyeCare Comparative Effectiveness Research Team (ECCERT) Assessment of vision-related quality of life among patients with cataract and the outcomes of cataract surgeryusing a newly developed visual function questionnaire; The VFQ-J11. Jpn J Ophthalmol, 2014; 58: $415-422$.

2) Kawasaki R, Akune Y, Hiratsuka Y, Fukuhara S, Yamada M: Cost-utility analysis of screening for diabetic retinopathy in Japan: a probabilistic Markov modeling study. Ophthalmic Epidemiol, 2015; 22: 4-12.

3) Tamura H, Goto R, Akune Y, Hiratsuka Y, Hiragi S, Yamada M: The clinical effectiveness and cost-effec- tiveness of screening for age-related macular degeneration in Japan: a Markov modeling study. PLoS ONE, 2015; 10: e0133628.

4) Kakigi C, Kasuga T, Wang SY, et al: Hypothyroidism and glaucoma in the United States. PLoS ONE, 2015; 10: e0133688.

\section{4) Clinical retina research}

\section{Miki HONDA (Associate Professor)}

Nobuyuki EBIHARA (Professor)

The retina research group comprises clinical scientists with a broad focus and expertise in basic translational and clinical research in the molecular mechanisms, pathways, and management of retinal disorders. Particularly, our group is focused on diabetic retinopathy, proliferative retinopathy, and age-related macular degeneration (AMD).

Publications:

1) Ogura Y, Terasaki H, Gomi F, et al: Efficacy and safety of intravitreal aflibercept injection in wet age-related macular degeneration: outcomes in the Japanese subgroup of the VIEW 2 study. Br J Ophthalmol, 2015; 99: 92-97.

2) Honda M, Asai T, Oku N, Araki Y, Tanaka M, Ebihara N: Liposomes and nanotechnology in drug development: focus on ocular targets. Int J Nanomedicine, 2013; 8: 495-503.

\section{5) Cornea and ocular surface}

\section{Hiroshi TOSHIDA (Senior Associate Professor) Satoru NAKATANI (Associate Professor) Toshinari FUNAKI (Associate Professor)}

Our main focus is on the diagnosis and treatment of corneal and ocular surface diseases, such as dry eye and meibomian gland dysfunction, as well as on the understanding of the molecular bases of these diseases.

Publications:

1) Toshida H, Ohta T, Suto C, Murakami A: Effect of subconjunctival lacrimal gland transplantation in a rabbit dry eye model. Cornea, 2013; 32 Suppl 1: S46-51.

2) Yamaguchi M, Shima N, Kimoto M, Ebihara N, Murakami A, Yamagami S: Markers for distinguishing cultured human corneal endothelial cells from corneal stromal myofibroblasts. Curr Eye Res, 2015; 40: 1211-1217.

3) Kimoto M, Shima N, Yamaguchi M, Hiraoka Y, Amano S, Yamagami S: Development of a bioengineered corneal endothelial cell sheet to fit the corneal curvature. Invest Ophthalmol Vis Sci, 2014; 55: 2337-2343.

4) Nakatani S, Murakami A: Three-year outcome of Descemet stripping automated endothelial keratoplasty for bullous keratopathy after argon laser iridotomy. Cornea, 2014; 33: 780-784. 